\title{
Effect of Change Management on Employee's Performance in Nigeria Universities
}

\author{
*Festus Onyegbula EKECHI Dr. Abbas Ibrahim UMAR \\ Department of Business Management, Nile University, Abuja-Nigeria
}

\begin{abstract}
University employees are professionals with main aim of transforming, developing, diffusing and disseminating science, technology, and arts; skills, abilities and capabilities through teaching, research, public, and community service. The job performance of employees seems to depend on change management strategies used in the university system. The study therefore examined effect of change management on employee's performance in universities in Federal Capital Territory, Abuja-Nigeria. Three research questions were raised and answered, while one hypothesis was formulated and tested. The descriptive survey research design was adopted for the study and total population was 3627 employees in five universities in Federal Capital Territory, Abuja. Proportionate stratified random sampling technique was used to select 315 employees for the study. Self-developed questionnaire was used to collect data from the study participants. The instrument was validated by research experts and subjected to test-retest reliability technique. Data collected were analysed using frequency count, percentage count, mean, and Multiple Regression Analysis. The hypothesis was tested at 0.05 level of significance. The findings showed that: there is low extent of technological and organizational leadership changes existence in Nigerian Universities, high extent of employee's performance in Nigerian universities, and change management indicators (technological change and organisational leadership change) raised are significant in determining employee's performance in Nigerian universities. The study concluded that there was acceptable employee's performance which can be determined by change management factors (technological changes and organizational leadership). It was therefore, recommended among others that: designing change management processes in the university, should be based on employees' functionalities (teaching, research and community services) and relationships in terms of their perception, norms, virtues and behaviours.
\end{abstract}

Keywords: change management, employee's performance, organizational leadership, technological changes, university

DOI: $10.7176 / \mathrm{EJBM} / 12-20-05$

Publication date:July $31^{\text {st }} 2020$

\section{Introduction}

Universities in Nigeria are established to promote and encourage national unity, scholarship and community service, international interaction, inculcate proper values for the survival of the individual and the society, as well as, develop individuals' physical, emotional and intellectual skills and knowledge for self-reliance and national development. These objectives of university education in Nigeria can be achieved through impressive and potent teaching, innovative research, effective community service and other potent allied academic activities performed by the employees. University employees are professionals with main aim of transforming, developing, diffusing and disseminating science, technology, and arts of any nation as well as develop individuals' skills, abilities and capabilities. The university employees have various tasks and role functions to accomplish and these range from teaching, research and publications, marking of tests and examinations, supervising students' research activities, supporting students through advisory roles, attending conferences, and providing community services (Akpan, 2014). The job performance of employees seem to depend on change management strategies used in the university system.

Change management seems to be imperative for university employees to carry out their job effectively and efficiently in this era of innovative development. Change is a process that is constant and inevitable in any situation. The Society for Human Resources Management (2015) defines change management as the systematic approach and application of knowledge, tools and resources to deal with change. Strategic management functions of university leadership in terms of planning, organizing, coordinating, reporting, directing, evaluating, communicating, employees' motivation and delegating should determine the employees' adaption of constant changes and innovation initiated by the university management. Change management is the series of new events, development, operations and rightsizing which support organizational effectiveness. Most Nigerian public and private universities have undergone series of management changes in all ramifications. Wanza and Nkuraru (2016) buttressed that Universities in Africa have gone through tremendous changes due to growth and expansion of institutions of higher learning. This has made the employees to embrace and adapt to the diverse change management factors. These factors are: organizational structure, technological changes, organizational leadership and organizational culture. The study considers technological and organizational leadership changes as essential to employee's performance. 
Technological changes seem to be important to job performance of university employees. Technology is essential to every nation and its usage has grown at a phenomenal rate within organisation. Pohekar (2018) posits that technology is a collaborative tool that supports traditional subjects and makes it convenient for the users to exchange information with others. In the last two decades, there has been rapid high-technology implementation changes that will continue to determine future of the world in terms of policies, programmes, activities, operations and strategies. All the universities in Nigeria have invested heavily on technological tools since its advent. Changes and advancement in technological tools in the university seems to determine the improvement of employee's performance, reduce human effort and task completion time. Imran, Maqbool and Shafique (2014) confirmed that changes and advancement of technological instruments appear to have determined the way employees perform their job, as well as, reduce workload.

In the same way, it seems that organizational leadership changes play major roles in job performance of university employees in Nigeria. Leaders in organisations initiate strategic changes and processes, in which the sustainability of the employees' and organizational performance may be modified. Leadership is one of the management functions that involves a process by which a person called the leader is involved in the responsibility of directing the activities of people, that is, its subordinates or followers towards the achievement of predetermined goals (Ibrahim \& Daniel, 2019). Organisational leadership change is the capability, aptitude, attitude, and dexterity of the university managers and administrators to create, conceive, diffuse, disseminate and annunciate visions, manage conflicts and conquer resistance to change. The ability to influence and inspire other people through personal advocacy, vision and drive, and to access resources to build a solid platform for change (Higgs \& Rowland, as cited in KbManage, 2020). Korbi (2015) opine that leadership change (either major or marginal) marks the discontinuity between past situation towards a new equilibrium or a refinement of the current situation.

Leadership changes always occur in organisations and subordinates resist it sometimes. Most times, leadership changes pull people out of their comfort zones and make them to adapt to habits that are not comfortable to them. For instance, university employees that do come to work at $11 \mathrm{am}$, may be told by the Dean of the Faculty or College to start work at $8 \mathrm{am}$ and he or she must sign the log-in and out book. This particular decision can make the employees to be uncomfortable and resistance may occur. Job performance of university employees seem to be determined by leadership changes that involves interpersonal skills and instrumental roles. Wuestman and Casey (2015) attest that leadership communication strategies and working together with the group of employees may sustain the long-term process changes in the job performance of employees.

It is against this background that the study examines effect of change management on employee's performance in universities in Federal Capital Territory, Abuja-Nigeria.

\section{Statement of the Problem}

The study problem was perceived poor job performance of university employees in Nigeria. Nowadays, the performance of university employees seem to be characterised with lateness to work by non-teaching staff, lecturers' lateness to lecture theatre, incessant absence from lecture rooms, poor instructional delivery, unacceptable supervising practices of students' research activities, non-attendance of research conferences, work truancy by non-teaching staff and poor community service rendering. Many reasons may be attributed to these derelictions of employees' service delivery, but this study examined employee's performance in relation to change management.

It appeared that many universities in Nigeria have occasionally gone through a lot of restructuring change processes due to innovative development scenarios. It appeared that Nigerian universities have not fully adapt to the world's technological changes. The universities seem to have defects in the acquisition and maintenance of innovative technological change. It also appeared that Nigerian universities are symbolized with deficiencies and a lot of flaws in organizational leadership change practices. It has been observed that various change management hazards have occurred in many universities in Nigeria. Daniel (2019) observed that the university's top echelons are suspected of serving only their interest by manipulating relevant change management data. This pose a tremendous threat to the attainment of university goals and objectives, as well as, production of quality manpower for the nation's economy.

It is assumed that if all these observed challenges persist in Nigerian universities, it may lead to continuous poor employee's performance. Furthermore, to the researcher's best knowledge, attention has not really been given by researchers to examine employee's performance in relation to change management in Nigerian universities. It is on this premise that the study therefore, examined effect of change management on employee's performance in universities in Federal Capital Territory, Abuja- Nigeria.

\section{Purpose of the Study}

The study aimed to examine effect of change management on employee's performance in universities in Nigeria. Specifically, it seeks to: 
1. Examine the extent to which technological change influences employee's performance.

2. Determine the effect of organizational leadership change on employee's performance.

3. Ascertain the extent at which university employees are effective at work.

4. Determine the joint and relative contributions of technological change and leadership change to the prediction of employee's performance.

\section{Research Questions}

The following research questions were raised and answered:

1. What is the extent to which technological change influences employee's performance?

2. What is the effect of organizational leadership change on employee's performance?

3. What is the extent at which university employees are effective at work?

\section{Research Hypotheses}

The following null hypothesis were formulated for the study:

$\mathrm{H}_{01}$ : technological change does not has significant influence on employee's performance.

$\mathrm{H}_{02}$ : There is no significant influence of organizational leadership change on employee's performance?

$\mathrm{H}_{03}$ : Technological change and organisational leadership change do not have significant joint and relative contributions in determining employee's performance.

\section{Literature Review Concept of Change Management}

Change is inevitable, unavoidable and necessary process of becoming different in order to achieve stated objectives of the organisation. Nowadays, organisations have realized the essence of change management practices. Daniel (2019) defined change management as a process that involves the unfreezing, moving and refreezing values, practices and procedures within an organisations. It is a systematic and organised application or approach (in organizational structure, leadership, culture and technology) that determine employees' organizational changes from a particular state to desired future state. The roles of managers during change in an organisation are: communicator, advocate, coach, liaison and resistance. Ndahiro, Shukla and Oduor (2015) view change management as an approach which requires adaptation and interpretation by professionals in order to ensure most suitable fit between organisations' strategies and plans.

Kimhi, Oliel, Okeke, Oboreh, Nebolisa and Esine (2019) defined change management as a necessary process of defining and adopting corporate strategies, structure, technologies and procedures to deal with changes in external conditions and business environment. Change management is a systematic process of dealing with perspective change of an individual and organisations. It is a systematic and organised application or approach that determine employees' organizational changes from a particular state to desired future state. Change management factors are organizational structure, leadership, culture and technology. The roles of managers during change in an organisation are: communicator, advocate, coach, liaison and resistance.

\section{Concept of Employee's performance}

The job performance of academic staff in Nigerian universities is a major component that determines the goals achievement of research, teaching and community service. Sinha (as cited in Methode, Osunsan, Irau, Wandiba, Abiria \& Bayo, 2019) posits that job performance of university employees depend on the willingness and openness of the employees to do the job. Every organisations including the university need the employees (lecturers) who are willing to do more than their usual job scope and contribute performance that exceed goals' and objectives' expectations. Agba and Ocheni (2017) postulate that boosting the performance of academic staff in Nigerian universities has remained a challenging problem to the management.

The basic functionalities of University employees are teaching, research, public service and other related roles and responsibilities. The teaching roles of universities employees involves preparation, planning and delivering of lectures, marking and grading scripts, supervision of students on industry training and teaching practice, development of innovative teaching methods, students' consultation and production of teaching materials for students among others. Research roles of university employees, according to Agbionu, Anyalor and Nnwali (2018), are carrying out investigations on identified problem(s), presentation of findings of such investigations in conferences/seminars and publishing the findings in journals and/or text books. The third role of university employees is community or public service rendering to the school and community at large.

\section{Technological Change and Employee's Performance}

Conditional performance of the universities are determined by the technological changes initiated. Technological changes are innovative advancement and development that facilitate communication improvement, task accomplishment and higher levels of work effectiveness and efficiency. Imran, Maqbool and Shafique (2014) define technological changes as the process of combining and reorganizing knowledge in order to generate new 
ideas, by using electronic devices or tools. Pohekar (2018) postulates that technological changes in the university occurs mostly in the following areas: timetabling, student admission and tracking, examination results and transcripts, finance database, human resources database, and information management.

Kute and Upadhyay (2014) conducted a study on the relationship between technological changes and employee performance in commercial printing industry. The findings showed that technological changes affect employee's performance in various ways like redundancy, employee turnover and the level of motivation at work. It was noted that technological changes affected skills and performance of the employees in the commercial printing industry. Imran, Maqbool and Shafique (2014) conducted a study on the impact of technological advancement on employee performance in banking sector. The researchers administered 140 copies of questionnaire, out of which 100 were get completed and returned. Regression analysis is used to check the impact of technological advancement on employee performance. Findings showed that technological advancement has significant impact on motivation and training of employees. Moreover as the concerned for technological advancement and employee performance, there is significant relationship among them.

\section{Organizational Leadership Change and Employee's performance}

As organizational comparative advantage becomes increasing, leadership change is gaining essentiality in driving effectiveness, performance and efficiencies of employees. Lecturers are main drivers of the university organisation. Organisational leadership change is the process of influencing and directing the activities of organised group of persons towards understanding values in the change policies and practices initiated by the management (Adebakin \& Gbadamosi, as cited in Ibrahim \& Daniel, 2019). Korbi (2015) defined organizational leadership change as someone who is an agent of influence that possess the abilities and capabilities to build the confidence of other employees, convince them of the need for strategic change, overcome their resistance and set-up socio-political support for the new strategy.

Organisational leadership change is the capability of an individual to associate, relate, influence and motivate a group of people towards the achievement of set goals, missions, visions and objectives of an organisation. Effective and strong leadership change strategies in the university often boost or determine the performance and effectiveness of lecturers. Othman, Saad, Robani and Abdullahi (2014) opine that appropriate leadership change strategies often play crucial roles in fostering culture that encourages knowledge sharing and employee retention, as well as, create loyalty to the university's goals and objectives. When there is no effective leadership in an organization no changes will be made, because there are no leaders that motivate and lead the organization's employees as well as provide a clear direction for the organization (Atkinson, as cited in Methode, Osunsan, Irau, Wandiba, Abiria \& Bayo, 2019). In the study of Attah, Obera \& Isaac (2017) titled effective leadership and change management for sustainable development in Nigeria. The study findings showed that effective leadership is the key to success of every organization, for Nigeria to achieve sustainable development, our leaders have greater role to play.

\section{Reviewed of Empirically Related Studies}

Kimhi, Oliel, Okeke, Oboreh, Nebolisa, \& Esione (2019) conducted a survey study on change management and organizational performance in manufacturing companies in Anambra state, Nigeria. Descriptive survey design was adopted, and primary data was employed. The population for the study was 286 employees working at the selected manufacturing companies in Anambra State. The entire population was used as the sample size for this study. The research instrument used for data collection was questionnaire. Content Validity was adopted, and the test-retest method was used to test validity and reliability of the research instrument. The study found that technological changes have a positive significant effect on organizational performance in manufacturing companies. Change management strategies have a positive significant effect on organizational performance in manufacturing companies in Anambra state. Leadership changes have a positive significant influence on organizational performance in manufacturing companies in Anambra state. The study concluded that change management has a positive significant effect on organizational performance in manufacturing companies in Anambra state.

Olajide (2014) empirically examined the effect of change management on organizational performance of Nigerian telecoms industries. Three research hypotheses were formulated. The study randomly selected a total of 300 staffs of Airtel from a staff population of 1000. Data collected for the study were analyzed using One-way Analysis of Variance. The result revealed that changes in technology has a significant effect on performance and that changes in customer taste has a significant effect on customer's patronage. The result also shows that changes in management via leadership has a significant effect on employee's performance.

\section{Theoretical Framework}

The study was anchored on Social Exchange Theory, propounded by Geroge Homans in 1950. It is also known as action-reaction theory, while some scholars called it stimulus-response theory. It is a theory that determines the 
voluntary actions of individuals. Social exchange theory has been applied to almost every type of situation such as: organizational management, consumer buying decisions, politics, and marriage (Redmond, 2015). Redmond buttressed that this theory focuses on the improvement of equity, distributive justice, equilibrium, social influence, conformity and cohesiveness.

The theory states that it is the actions or stimulus change initiated by leadership of an organisation that lead to the voluntary reactions and responses of employees. The thrust of this study was that change management actions, stimulus or practices initiated by university leadership, determines the voluntary reactions and responses of the employees towards job performance.

\section{Research Methodology}

The study adopted descriptive research design. The research design was appropriate because it allows the collection, description, analyses and interpretation of data in order to make relevant inference. The population of the study was 3627 employees (1289 lecturers and 2338 non-teaching staff) in five universities in Federal Capital Territory, Abuja

(National Universities Commission, 2018). The universities are: University of Abuja, Nile University, Baze University, Veritas University, and African University of Science and Technology. Digeebird statistics calculator software was used obtain a sample size of 315 and proportionate stratified random sampling technique $\left(n / N\right.$ x $\left.S_{S}\right)$ was used to select 315 employees for the study.

Research instrument used for the study was a self-developed questionnaire, which was subjected to both face and content validity by two experts in the Department of Business Management, Nile University. The reliability of the instrument was determined by the use of test-re-test technique. Cronbach Alpha Coefficient was used to establish internal consistency and Alpha coefficient value obtained was 0.72 . The researcher with the help of four trained research assistants administered 315 copies of questionnaire, and 300 copies of the questionnaire were returned and good for analysis. This represented 95.2\% return rate which is high enough for the study. Data collected were analysed using frequency count, mean, percentage and Regression statistical tools.

\section{Results Presentation and Analyses}

This section presents results and analyses of answers to the research questions and test of research hypotheses.

\section{Answers to the Research Questions}

Research Question One: What is the extent to which technological change influences employee's performance? Table 1: Extent of technological change existence in the Universities

\begin{tabular}{|c|c|c|c|c|c|}
\hline$\overline{\mathbf{S} / \mathbf{N}}$ & Statements & $\underline{\text { Yes }}$ & $\underline{\%}$ & $\underline{\text { No }}$ & $\underline{\%}$ \\
\hline 1 & Is your office connected to the internet? & 228 & $\overline{76}$ & 72 & $\overline{24}$ \\
\hline 2 & Do you have an institutional email address? & 225 & 86 & 42 & 14 \\
\hline \multirow[t]{2}{*}{3} & Do you disseminate students' score to the department using electronic media? & 135 & 45 & 165 & 55 \\
\hline & & $\begin{array}{l}\text { High } \\
\text { Extent }\end{array}$ & & & $\%$ \\
\hline & $\begin{array}{l}\text { To what extent does your Head of Department use electronic media to } \\
\text { disseminate information on course allocations to employees? }\end{array}$ & 108 & 36 & 192 & 64 \\
\hline 5 & $\begin{array}{l}\text { To what extent does your Head of Department use electronic media to disseminate } \\
\text { examination timetables to employees and students? }\end{array}$ & 114 & 38 & 186 & 62 \\
\hline 6 & $\begin{array}{l}\text { To what extent does your Head of Department use electronic media to } \\
\text { conduct departmental meetings? }\end{array}$ & 27 & 09 & 273 & 91 \\
\hline 7 & To what extent do records management in your institution done electronically. & 162 & 54 & 138 & 46 \\
\hline
\end{tabular}

The result on table 1 shows that, $76 \%$ of the participants responded positively to their offices connected to the internet, while $24 \%$ of the participants responded negatively. The finding also shows that, $86 \%$ of the participants responded positively to having institutional email address, while $14 \%$ of the participants responded negatively. The finding also shows that $45 \%$ of the participants responded positively to disseminate students' score to the department using electronic media, while $55 \%$ of the participants responded negatively. The result also shows that $36 \%$ of the participants, responded high extent to their Heads of Department using electronic media to disseminate information on course allocations to employees, while $64 \%$ of the participants responded low extent. The result also shows that $38 \%$ of the participants responded high extent to their Heads of Department using electronic media to disseminate examination timetables to employees and students, while $62 \%$ of the participants responded low extent. The result also shows that $9 \%$ of the participants, responded high extent to their Heads of Department using electronic media to conduct departmental meetings, while $91 \%$ of the participants responded low extent. The result also shows that $54 \%$ of the participants responded high extent to their institutions using electronic media to management records, while $46 \%$ of the participants responded low extent.

Research Question Two: What is the effect of organizational leadership change on employee's performance? 
Table 2 Extent of organizational leadership change existence in the Universities

\begin{tabular}{|c|c|c|c|c|c|}
\hline$\underline{\mathbf{S} / \mathbf{N}}$ & Statements & High Extent & $\%$ & Low Extent & $\%$ \\
\hline 1 & $\begin{array}{l}\text { To what extent does your Head of Department encourage } \\
\text { staff professional development? }\end{array}$ & 159 & 53 & 141 & 47 \\
\hline 2 & $\begin{array}{l}\text { To what extent does your Head of Department allocate work, } \\
\text { based on depth of knowledge of the lecturer? }\end{array}$ & 186 & 62 & 114 & 38 \\
\hline 3 & $\begin{array}{l}\text { To what extent does your Head of Department translate his } \\
\text { or her goals to members of the department? }\end{array}$ & 165 & 55 & 135 & 45 \\
\hline 4 & $\begin{array}{l}\text { My Head of Department do encourage his or her } \\
\text { subordinates to get involve in decision making? }\end{array}$ & 99 & 33 & 201 & 67 \\
\hline 5 & $\begin{array}{l}\text { To what extent do members of the department } \\
\text { understand the HOD's change of plans earlier initiated? }\end{array}$ & 129 & 43 & 171 & 57 \\
\hline 6 & $\begin{array}{l}\text { To what extent does your Head of department establish } \\
\text { sense of urgency for change of plan needs? }\end{array}$ & 132 & 44 & 168 & 56 \\
\hline
\end{tabular}

The result on table 2 shows that, $53 \%$ of the participants responded positively to their HODs encouraging staff professional development, while $47 \%$ of the participants responded negatively. The finding also shows that, $62 \%$ of the participants responded positively to their HODs allocating tasks, based on depth of knowledge of the lecturer, while $38 \%$ of the participants responded negatively. The finding also shows that $55 \%$ of the participants responded positively to their HODs translating their goals to members of the department, while $45 \%$ of the participants responded negatively. The result also shows that $33 \%$ of the participants, responded high extent to their HODs encouraging their subordinates to get involve in decision making, while $67 \%$ of the participants responded low extent. The result also shows that $43 \%$ of the participants responded high extent to members of the department understanding the HOD's change of plans earlier initiated, while $57 \%$ of the participants responded low extent. The result also shows that $44 \%$ of the participants, responded high extent to their Heads of Department establishing sense of urgency for change of plan needs, while $56 \%$ of the participants responded low extent.

Research Question Three: What is the extent at which university employees are effective at work?

Table 3 Extent at which university employees are effective at work

\begin{tabular}{|c|c|c|}
\hline $\mathbf{S} / \mathbf{N}$ & Statements & Mean \\
\hline 1 & when do you give different assignments to the students? & 2.73 \\
\hline 2 & When do you administer test to assess students' learning? & 3.81 \\
\hline 3 & When do you present summary of previous lessons? & 3.79 \\
\hline 4 & How often do you involve students in the planning of classroom activities? & 2.60 \\
\hline 5 & How often do you review marked assignments with the students? & 2.83 \\
\hline 6 & When do you allow the students to ask questions? & 2.70 \\
\hline 7 & When do you encourage the students to participate in the class activities? & 3.83 \\
\hline 8 & When do you return marked test paper back to the students? & 2.64 \\
\hline
\end{tabular}

Mean Midpoint $=2.50$

Responses to table 3 reported that majority of the participants were in agreement with the fact that: they give different assignments to the students $(\mathrm{M}=2.73>2.50)$; they do administer test to assess students' learning $(M=3.81>2.50)$, and they do present summary of previous lessons $(M=3.79>2.50)$. Similarly, most of the participants were in agreement that they do: involve students in the planning of classroom activities $(\mathrm{M}=2.60>2.50)$; review marked assignments with the students $(\mathrm{M}=2.83>2.50)$; and allow the students to ask questions $(\mathrm{M}=2.70>2.50)$. In addition, university lectures: encourage the students to participate in the class activities $(M=3.83>2.50)$ and return marked test paper back to the students $(M=2.64>2.50)$.

\section{Test of Research Hypotheses}

Hypothesis One: Technological Change does not have any significant influence on employee's performance. Table 4: Influence of Technological Change on Employee's Performance

\begin{tabular}{|c|c|c|c|c|c|c|}
\hline Variable & $\mathbf{N}$ & df & $\underline{X}^{2}$ & p-value & Remark & Decision \\
\hline Technological Change & & & & & & \\
\hline Employee's Performance & 300 & 16 & 143.09 & 0.033 & Significant & Reject: $\mathrm{H}_{\mathrm{o} 1}$ \\
\hline
\end{tabular}

The Chi-Square statistics is significant at the 0.05 level.

Chi-square was run to determine the influence of technological change on employee's performance. Table 4 shows that $\left.\chi^{2}(16, \mathrm{~N}=300)=143.09, \mathrm{p}<0.05\right)$. This indicated that there was significant influence of technological change on employee's performance. Thus, the hypothesis which stated that there is no significant influence of 
technological change on employee's performance is rejected.

Hypothesis Two: Organisational leadership change does not have any significant influence on employee's performance.

Table 5:

Influence of Organisational Leadership Change on Employee's Performance

\begin{tabular}{lllllll}
\hline Variable & N & df & $\mathbf{X}^{\mathbf{2}}$ & p-value & Remark & Decision \\
\hline Organisational leadership Change & 300 & 16 & 128.2 & 0.011 & Significant & Reject: $\mathrm{H}_{\mathrm{o} 1}$ \\
Employee's Performance & & & & & & \\
\hline
\end{tabular}

The Chi-Square statistics is significant at the 0.05 level.

Chi-square was run to determine the influence of organisational leadership change on employee's performance. Table 5 shows that $\left.\chi^{2}(16, \mathrm{~N}=300)=128.2, \mathrm{p}<0.05\right)$. This indicated that there was significant influence of organisational leadership change on employee's performance. Thus, the hypothesis which stated that there is no significant influence of organisational leadership change on employee's performance is rejected.

Hypothesis Three: Technological change and organisational leadership change do not have significant joint and relative contributions in determining employee's performance.

Table 4

\begin{tabular}{|c|c|c|c|c|c|}
\hline Model & $\mathbf{R}$ & R Square & Adjusted R Square & $\begin{array}{l}\text { Std. Error of the } \\
\text { Estimate }\end{array}$ & $\begin{array}{l}\text { Durbiн } \\
\text { Watson }\end{array}$ \\
\hline 1 & .693 & .480 & .476 & 2.35513 & 2.436 \\
\hline
\end{tabular}

a. Predictors: (Constant), Technological Change, Organisational Leadership Change.

\section{Joint Contribution of the Independent Variables to the Dependent Variable}

b. Dependent Variable: Employee's performance.

Multiple regression analysis was run to determine the joint and the relative contributions of technological change and organisational leadership change, to employee's performance. It is shown from Table 4 that the two independent factors namely: technological change and organisational leadership change have positive multiple correlation with employee's performance $(\mathrm{R}=0.693)$. Also the adjusted $\mathrm{R}^{2}$ value of 0.476 indicated that the two selected variables jointly contributed

$47.6 \%$ to the variance in the dependent variable, that is, employee's performance. By implication, the remaining $52.4 \%$ is due to residuals, that is, those variables not included in the study. However, in order to determine whether or not the adjusted $\mathrm{R}^{2}$ value obtained above is significant, the Analysis of Variance (ANOVA) was run in Table 5.

Table 5 Analysis of Variance showing the relationship among the collaborative activities in Change Management indicators and Emolovee's nerformance

\begin{tabular}{llccccc}
\hline Model & & Sum of Squares & Df & Mean Square & F & Sig. \\
\hline \multirow{2}{*}{1} & Regression & 1518.596 & 2297 & 759.298 & 136.893 & $.001^{b}$ \\
& Residual & 1647.351 & & 5.547 & & \\
& Total & 3165.947 & 299 & & &
\end{tabular}

a. Dependent Variable: Employee's performance

b. Predictors: (Constant), Leadership Change, Technological Change

Evidence in Table 5 shows that the calculated F-Value is 136.893 , and it is statistically significant at $\mathrm{p}<0.05$. Thus, the hypothesis which states that technological change and organisational leadership change, do not have significant joint and relative contributions in predicting employee's performance was rejected. This means that, there was significant joint contribution of technological change and organisational leadership change, to employee's performance. This implies that the obtained adjusted $\mathrm{R}^{2}$ value was not due to chance. This implies that regression model is a good fit of the data. Hence, the selected change management factors should be taken into consideration in the determination of employee's performance. To determine the relative contributions of each of the two selected indicators of change management on employee's performance, their relative $\beta$-values and their corresponding p-values were established and the results are presented in Table 6. 
Table 6

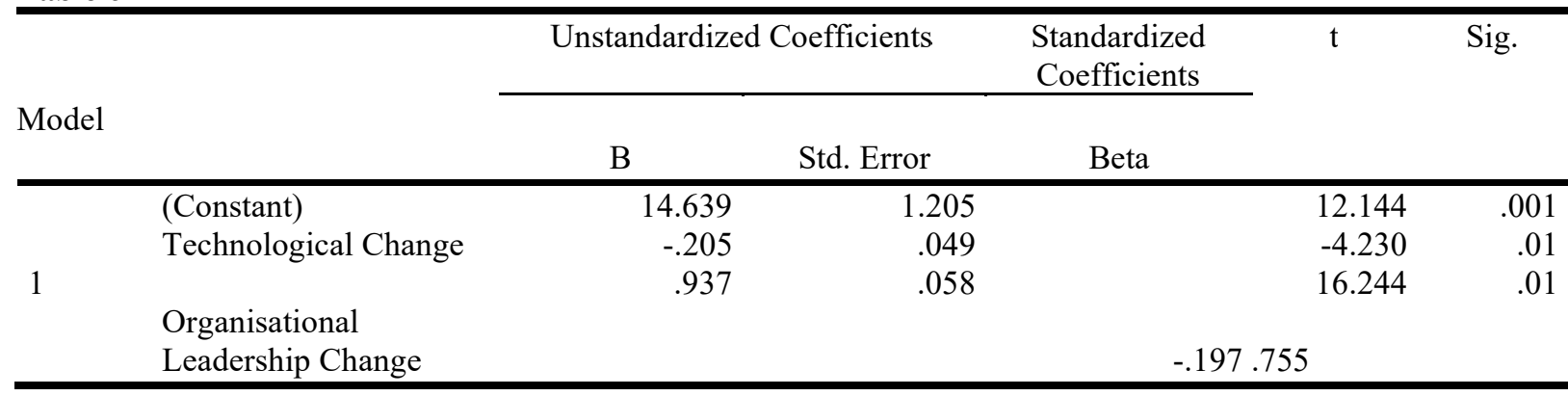

a. Dependent Variable: Employee's performance

Illustration in Table 6 shows that each of the selected variables namely: technological change and organisational leadership change contributed differently to employee's performance. Their relative contributions in order of importance are: organisational leadership change $(\beta=0.755 ; p=0.01<0.05)$, and technological change $(\beta=-0.197$; $\mathrm{p}=0.01<0.05)$. This result means that, all the variables contributed significantly. Thus, organisational leadership change contributed most to employee's performance.

\section{Discussion of Findings}

Research hypothesis one which states that technological change does not have significant influence on employee's performance in Nigerian universities was rejected; while the alternative hypothesis was accepted. The study also shows that there is low extent of technological changes existence in Nigerian Universities. This implies that, most Nigerian universities' responses to the adoption and adaption of technological change initiated into the higher education system is very low. This result is in line with the findings of Egoeze, Misra, Maskeliunas and Damasevicious (2018) which indicates that Nigerian universities have not fully integrate Information and Communication Technology (ICT) changes in the general administration, teaching, learning and research. The reason for this result findings of the study was that proper and effective integration of technological changes in the university system will enhance maximum effectiveness and efficiency of employees' service delivery.

Research hypothesis two which states that there is no significant influence of organizational leadership changes on employee's performance in Nigerian universities was rejected; while the alternative hypothesis was accepted. The study also shows that there is low extent of organizational leadership change existence in Nigerian universities. This implies that Heads of Departments (HODs) do not usually carry members of the department along when there are changes in plans earlier initiated. The result aligns with the findings of Ibrahim and Daniel (2019) which states that there is need for HODs in Nigerian universities to establish sense of urgency with all members of the department, when there is changes in plan in order to handle subordinates' resistance during implementation. The reason for this result findings of the study was that appropriate leadership change initiated by HODs in Nigerian universities breeds the requisite condition that helps to stimulate resistance and enhance employees' performance, as well as foster conducive work climate.

Research question three shows that there is high extent of employee's performance in Nigerian universities. This finding contradicts the result of Agba and Ocheni (2017) which states that job productivity of employees in the Nigerian public sector including the universities, despite reforms and institutional capacity building efforts has been on persistent decline. But, the result findings shows that most university employees in Nigeria perform their duties, roles and responsibilities judiciously. The reason for this result findings of the study was that job performance of academic staff of Nigerian universities should be key issues and priority of universities management.

Research hypothesis three shows that technological change and organisational leadership change do have significant joint and relative contributions in predicting employee's performance. This implies that change management indicators (technological change and organisational leadership change) raised are significant in determining employee's performance in Nigerian universities. The result analyses show that organisational leadership change had the highest contribution to employee's performance, while technological change contributed the least. The result analyses corroborate with the study of Olajide, (2014) which maintains that technological changes have great influence in the prediction on employee performance, due to the rapid technological changes that the world is rapidly adjusting to. The result lends credence to the study of Hurduzeu (2015) which shows that organizational leadership change positively influences the employees' productivity. Therefore, the reason for this study findings, was that proactive change management strategies in the technological change and organisational leadership change, encourage the university employees to perform better in teaching, research and community service. 


\section{Conclusion}

Change has become re-occurring phenomenon in the human race. Proactive (not reactive) and appropriate change management strategies are essential factors in the job performance of university employees, which often transcend to the achievement of long and short-term goals and objectives of any organisation. The study concludes that change management indicators (technological and organisational leadership changes) influence job performance of university employees in Nigeria. The study also conclude that there is high level of employee performance among teaching and non-teaching employees of the Nigerian universities.

\section{Recommendation}

Based on the purpose of the study and result findings, the following recommendations are made:

1. The university management should implement and integrate the new technological changes and advancement into the system. The management should periodically train the university employees of new technological changes initiated into the system.

2. The university management should initiate appropriate leadership changes that is based on work values, norms, ethics, behaviours and perceptions. These leadership changes initiated should be able to help to stimulate good leader-subordinate relationships, and motivate the university employees to choose to participate or contribute to the growth and development of the university system.

3. The management of Nigerian universities should invest in the factors that will help to boost or motivate the employees to perform their job judiciously.

4. Designing change management processes in the university, should be based on employees' functionalities (teaching, research and community services) and relationships in terms of their perception, norms, virtues and behaviours.

\section{Suggestions for Further Studies}

This research on effect of change management on employee's performance in universities in Federal Capital Territory, Abuja-Nigeria was by no means exhaustive. Further studies could be carried out on the subject in the following areas:

1. The design aspect of this research adopted a descriptive survey, other studies could consider carrying out a study involving a correlational survey data collection process to provide a dependable attestation of the influences identified in this study.

2. Further studies can use in-depth interviews as qualitative data collection process to enrich the data collection process.

3. The study population can be executed on a larger geographical scope.

4. Additional studies should be conducted involving other variables not used.

\section{Reference}

Agba, M. S., \& Ocheni, S. I. (2017). An empirical study of the effects of work environment (electric power supply) on job performance of academic staff in Nigerian public and private universities. Higher Education of Social Science, 12 (2), 11-20.

Agbionu, U.C., Anyalor, M. \& Nnwali, A.C. (2018). Employee engagement and performance of employees in Nigerian tertiary institutions. Journal of Education \& Entrepreneurship, 5 (2), 69-87.

Akpan, C.P. (2014). ICT competence and employees' job efficacy in universities in Cross River State, Nigeria. International Journal of Humanities and Social Science, 4 (10), 259-266.

Attah, E.Y., Obera, V.A. \& Isaac, S. (2017). Effective leadership and change management for sustainable development in Nigeria. International Journal of Public Administration and Management Research, 4(2), $37-$ 42

Daniel, C. O. (2019). Effects of change management on the performance of firms in Nigeria. International Journal of Advances in Scientific Research and Engineering, 5 (1), 59-64.

Egoeze, F., Misra, S., Maskeliunes, R. \& Damasevicious, R. (2018). Impact of ICT on universities administrative services and management of students' records: ICT in university administration. International Journal of Human Capital and Information Technology Professionals, 9(2), 1-16.

Hurduzeu, R., (2015). The impact of leadership on organizational performance. SEA - Practical Application of Science, $\operatorname{III}(1)$.

Ibrahim A. U. \& Daniel C. O. (2019). Impact of leadership on organisational performance. International Journal of Business, Management and Social Research, 06(02), 367-374.

Imra, M., Maqbool, N. \& Shafique, H. (2014). Impact of technological advancement on employee performance in banking sector. International Journal of Human Resource Studies, 4 (1), 57-70.

KbManage (2020). Change leadership. Retrieved from https://www.kbmanage.com/concept/change-leadership.

Korbi, K. (2015). Leadership and strategic change. Retrieved from 
http://www.ibimapublishing.com/journals/JOMS/joms.html

Kute, D., \& Upadhyay, P., (2014). The impact of technological changes on the performance of the employees in commercial printing industry. Journal for Contemporary Research in Management, 2(3), 67-72

Methode, K., Osunsan, O.K., Irau,F., Wandiba, A., Abiria, P. \& Bayo, I. (2019). The effect of organizational change on employee performance among selected commercial banks in Bujumbura, Burundi. East African Scholars Journal of Economics, Business and Management, 2(4), 225-234.

Ndahiro, S., Shukla, J. \& Oduor, D. (2015). Effect of change management on the performance of government institutions in Rwanda: A Case of Rwanda Revenue Authority. International Journal of Business and Management Review, 3(5) $95-107$.

Kimhi, S., Oliel, Y., Okeke M.N., Oboreh, J.C, Nebolisa O., \& Esione, U.O. (2019). Change management and organizational performance in manufacturing companies in Anambra state, Nigeria. The International Journal of Social Sciences and Humanities Invention, 6(05), 5437-5445.

Olajide, O. T. (2014). Change management and its effects on organizational performance of Nigerian telecoms industries: Empirical insight from Airtel Nigeria. International Journal of Humanities Social Sciences and Education, 1(11), $170-179$.

Othman, F. S., Saad, M. S. M., Robani, A., \& Abdullah, A. N. (2014). A conceptual framework of the impact of leadership styles on heterogeneous R\&D Team performance. International Symposium on Research in Innovation and Sustainability, 3(7), 1759-1762.

Pohekar, d. (2018). Role of ICT on universities administrative services and management. International Research Journal of Engineering and Technology, 5(11), 266-271.

Redmond, M. V. (2015). Social exchange theory. Retrieved from https://lib.dr.iastate.edu/cgi/viewcontent.cgi?article=1003\&context=engl_reports

The Society for Human Resource Management (2015). Change management. Retrieved from www.shrm.org/templatestools/

Wanza, L. \& Nkuraru, J.K. (2016). Influence of change management on employee performance: A case of University of Eldoret, Kenya. International Journal of Business and Social Science, 7(4), 190-199.

Wuestman, D., C.M.A., \& Casey, J. (2015). Lean leadership: Sustaining long-term process change. Strategic Finance, 96(8), 15-16. 